\title{
Collaboration TPS Learning Model and m-Learning Based on Android for Understanding of Trigonometry Concepts with Different Cognitive Style
}

\author{
Silfanus Jelatu \\ STKIP Santu Paulus, Indonesia, silfanusjelatu@yahoo.co.id \\ Yohanes Kurniawan \\ STKIP Santu Paulus, Indonesia, yohaneskurniawan91@gmail.com \\ Valeria Suryani Kurnila \\ STKIP Santu Paulus, Indonesia, valeria.suryani@gmail.com

\section{Kanisius Mandur} \\ STKIP Santu Paulus, Indonesia, kanisiusmandur@gmail.com \\ Ricardus Jundu \\ STKIP Santu Paulus, Indonesia, rickyjundu@gmail.com
}

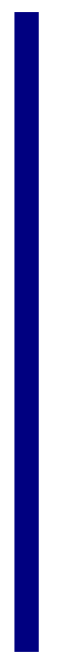

This research aimed to examine the effect of collaboration Think Pair Share (TPS) Leaning Model and m-Learning based on Android on the understanding of trigonometry concepts and to investigate the interaction between collaborative learning and cognitive style on the understanding of trigonometry concepts. This research involved 80 pre-service teachers of Mathematics Department at STKIP Santu Paulus Ruteng, Province of East Nusa Tenggara, Indonesia. The quasiexperimental research with control class without pre-test was done. Before the experiment, the Group Embedded Figures Test (GEFT) was used to identify students cognitive styles either Field-Dependent (FD) or Field-Independent (FI). The research data were obtained from a test consisting of five questions to measure students' understanding of trigonometry concepts. The data were then analyzed using two-way ANOVA. The results of the research show that 1) the collaboration of TPS Leaning Model and m-Learning based on Android leads to the higher achievement of the students on the understanding of trigonometry concepts if compared to students in conventional groups (expository). 2) there was no interaction effect between the collaborative learning and cognitive style of students' understanding of trigonometry concepts.

Keywords: TPS models, m-Learning, Android, conceptual understanding, trigonometry concept, cognitive style

Citation: Jelatu, S., Kurniawan, Y., Kurnila, V. S., Mandur, K., \& Jundu, R. (2019). Collaboration TPS Learning Model and m-Learning Based on Android for Understanding of Trigonometry Concepts with Different Cognitive Style. International Journal of Instruction, 12(4), 545-560. https://doi.org/10.29333/iji.2019.12435a 


\section{INTRODUCTION}

Trigonometry is one of the essential branches of mathematics education. Weber (2005) state that trigonometry is a pre-requisite for understanding topics in Newtonian physics, architecture, surveying, and many branches of engineering. Further, he described trigonometry as one of the earliest mathematics topics that link algebraic, geometric, and graphical reasoning; it can serve as an essential precursor towards understanding precalculus and calculus.

Trigonometry has a connection or benefit in the development of technology and the daily life of society. For example, trigonometry can be used to measure the height of a building or mountains, in video games, construction, flight engineering, used in navigation, and there are many other uses of trigonometry. Given the importance of trigonometry, the education curriculum in Indonesia, both curricula in secondary and tertiary education put trigonometry as one of the essential lessons in mathematics. According to Dündar (2015), teaching trigonometry theorems and concepts is necessary for developing students' creative, logical, and analytical thinking skills. The importance of trigonometric skills is also explained by Harrington (Harrington et al. , 2016) that students in the USA in the first semester in STEM (Science, Technology, Engineering, and Mathematics) courses are provided online without paying introductory mathematics courses before taking calculus courses and trigonometry. This preparatory mathematics online lecture is offered to support other massive courses in the following semesters such as calculus and trigonometry.

One of the essential competencies after learning trigonometry is a conceptual understanding or understanding of trigonometry concept. With conceptual understanding, students can unite ideas and processes and apply them to solving problems in their daily life. National Council of Teachers of Mathematics (NCTM, 2000) explains that conceptual understanding is one of the general principles and standards of school mathematics. In problem-solving processes, conceptual understanding is vital to understand mathematical knowledge and the relationships between knowledge structures (Dündar, 2015). Students need to be able to unite concepts and processes and apply them to solving problems. Many studies concerned with mathematics education explain that students have misconceptions and make errors (Usman \& Hussaini, 2017; Tuna, 2011; Tatar, Okur \& Tuna, 2008). Zakaria (2010) described these errors in solving mathematical problems often occur directly or inadvertently ranging from writing to oral and even computation. Most students who encounter the sine, cosine, tangent and cotangent concepts for the first time in their high school or university education cannot relate these concepts to real-life situations and do not know where they come from (Dündar, 2015).

Considering an understanding of trigonometry concepts is one of the competencies that must be owned, teachers must design the learning process effectively. Changes in the learning paradigm in primary, secondary, and tertiary institutions are one of the many recommendations from studies by several experts. One of them is recommended a learning approach that is oriented towards students (student centers) and following the development of technology. The old paradigm (teacher-centered approach), should be 
changed because it is considered traditional (Popescu et al. 2016). Nowadays, we have entered the knowledge era that has a million characters and breakthroughs based on knowledge and technology. This era has an impact on the learning patterns applied. The approach given must be up to date. The aim is that students can develop both individual and social competencies.

In Indonesia, the change of the curriculum is one of the adjustments to the national education system to answer the needs of future generations in an era dominated by automation or technology dominate. The primary objective of the government to overhaul the curriculum is to produce a crop that can survive in an age that demands the strength of this individual. One of the essential aspects emphasized in the Indonesian education curriculum is the importance of collaborative learning or integrating technology-based media into the learning process. Elmunsyah (2014) wrote that the learning and teaching plan in the new curriculum in Indonesia (the 2013 curriculum), shows that both technical coaching and improving ICT implementation in the curriculum are crucial. Collaborative learning as a pedagogical method in personal learning and collaborative experience, the application has been implanted schools to universities (Lee, 2011). The use of technology both computer and smartphone are directed to make quality changes in education, overcome the setbacks that occur, and open promising possibilities in the development of human potential. Jelatu et al. (2018) state that the use of ICT in education will provide dynamism in learning so that it can lead to student interest in learning. In this paper, we introduce collaboration learning by integrated Think Pair Share (TPS) Leaning Model and m-Learning based on Android as an alternative strategy for teaching trigonometry.

\section{LITERATURE REVIEW}

\section{Think Pair Share (TPS) Learning Model}

Think Pair Share (TPS) is one of many cooperative learning models. In TPS learning model students are directed in group learning activities in pairs and cooperate in solving mathematics problems. This model is based on togetherness through a process of cooperation between students to deepen the subject matter. There is an interaction between students and their groups in TPS models. Students with more abilities are directed to help students with lower skills so that all members in the group can understand the material being taught (Zubainur, \& Abidin, 2018; Leasa, \& Corebima, (2017).

Carrs (2007) revealed that the learning method was using the Think-Pair-Share method had a positive effect resulting in excellent achievements. In addition to the existence of collaborative learning groups teachers also make modifications in learning. The function of adjustment in education is one of the efforts that can be done by the teacher to provide new variations and types without losing the original concept. The results of the study show that cooperative learning is more beneficial than competitive learning.

The slogan by Beers (as cited in Sariyasa, 2017) that "I swim your sink, you swim I sink" is no longer suitable so it is replaced by "swim or sink together. " By working in small groups (two or three people), students can share (share) thoughts when learning 
concepts so that they can help internalize trigonometric concepts (Afthina \& Pramudya,2017). In this case, students also simultaneously communicate (mainly oral) which can be used as a way to perfect understanding of the concepts.

\section{M-Learning based on Android}

Mobile learning is one of many answers to reform education. Laouris and Laouri (2008) presented that the change from e-Learning to m-Learning implied that the revolution did not change regarding but also in a mindset of learning environments. Mobile learning opens the boundaries of learning to support learners to learn anytime. Mobile learning is a form of adaptation to technological progress by developing teaching methods from traditional face-to-face teaching to computer-based learning systems (CBL). Mobile learning will be able to serve the needs of heterogeneous students (different interests and talents), the learning process will be oriented to all students, as well as the creation of the ability to learn for life rather than devour knowledge. Mobile learning assists students in creating social interaction; it promotes collaborative learning, interactivity, and instant feedback as well as collaboration between peers; it improves their knowledge structure; their learning achievements and motivation (Mouza and BarrettGreenly, 2015).

In the implementation of m-Learning, mobile devices such as smartphones are used. The development of smartphones has changed human life by giving the facilitating interaction between human and machine. Smartphones which have been used recently use Android as an operating system. An increasingly affordable Android smartphone which can be purchased by almost everyone as a tool to communicate (Gunawan, 2017). Smartphone base Android operating system also can support our activities effectively in everyday life. Meiliana (2018) described that Android is the most popular mobile operating systems on the market. Meilina share in 2nd Quarter 2017 Android operating system gets $87.7 \%$ of the mobile operating system on the market share. Android is an open source mobile device operating system developed by Google based on the Linux 2.6 kernel. It is an open source giving developers chances to build their applications so all Android users can download the apps in play store (Astra, Nasbey, \& Nugraha, 2015). There are many applications in the play store. It is often used by Android and has an open source nature that makes the gateway to the development of Android apps that can be utilized m-learning.

Many studies describe the effectiveness of using m-Learning base on Android application in improving mathematical abilities. Drigas \& Pappas (2015) in their article about the use of m-Learning applications in mathematics concluded that there was an influence in the learning process through the use of an Android smartphone or other interactive learning media. They find that Mobile Learning apps can improve arithmetic, numerosity, graphs' representation, geometrical objects construction, algebra problem solving and mathematical programming. Etcuban \& Pantinople (2018) concluded that online and mobile learning applications could increase student learning motivation, making mathematics more enjoyable and interactive than common teaching practices. Kularbphettong et al. (2015) in his research found that m-Learning based on Android 
operating systems can assist students to enhance student's abilities in discrete mathematics classes.

Toktarova et al. (2015) researchers from Russia suggested that the most effective use of learning facilities today is $\mathrm{m}$-Learning, namely the use of smartphone devices for learning. Martono \& Oky (2014) in their research revealed that the new trend of using elearning is to use mobile learning or m-learning that uses smartphones based on Android, IOS or Windows Phone. Etcuban \& Pantinople (2018) in their study about Effects of Mobile Application in Teaching High School Mathematics concluded that the use of the mobile application in teaching mathematics by using the mobile app had somehow helped enhanced students'achievement and learning.

The use of Android smartphones in learning has been widely studied, and many have already applied it especially in math learning. National Council of Teachers of Mathematics (NCTM, 2000) claims that "Technology is an essential tool for learning Mathematics in the 21 st century, and all schools must ensure that all their students have access to technology". Mobile learning as technology provides many opportunities for personal, informal and spontaneous, situated learning. Through the use of mobile devices, students of all age levels and backgrounds will be able to collaborate, engage and learn in different ways (Skillen, 2015).

In addition to primary and secondary schools, m-learning can also be used in universities. Kularbphettong et al. (2015) in his paper concluded that the m-Learning could be beneficial to use in different courses so that students can enhance and improve their ability and also this system supports teachers in the handle and manage their class. Teacher in learning mathematics used smartphone or tablet PCs for their lectures rather than writing on a blackboard or using a projector.

There are many conveniences and efficiency of using m-Learning in lectures. All material and questions will be listed on the tablet PC; students can get various examples and solutions on their tablets. Of course, they can keep lecture notes and will always be carried wherever and wherever they are. Galligan et al. (2010) made a demonstration of the potential of the Tablet PC and associated technologies for teaching mathematics in university or school settings. It provides some ideas on how Tablet PCs can be used in teaching mathematical sciences face-to-face and online at a distance. According to the students' feedback, the online sessions motivated them and enhanced communication with other students.

Collaboration TPS Learning Model with M-Learning based on Android for Teaching Trigonometry

Considering the importance of using media in learning mathematics, the researchers previously made an m-Learning base on the Android operating system as trigonometry learning media. This media was deliberately created for lecture advice at STKIP Santu Paulus Ruteng. Figure 1 showed the screenshot of the application. 


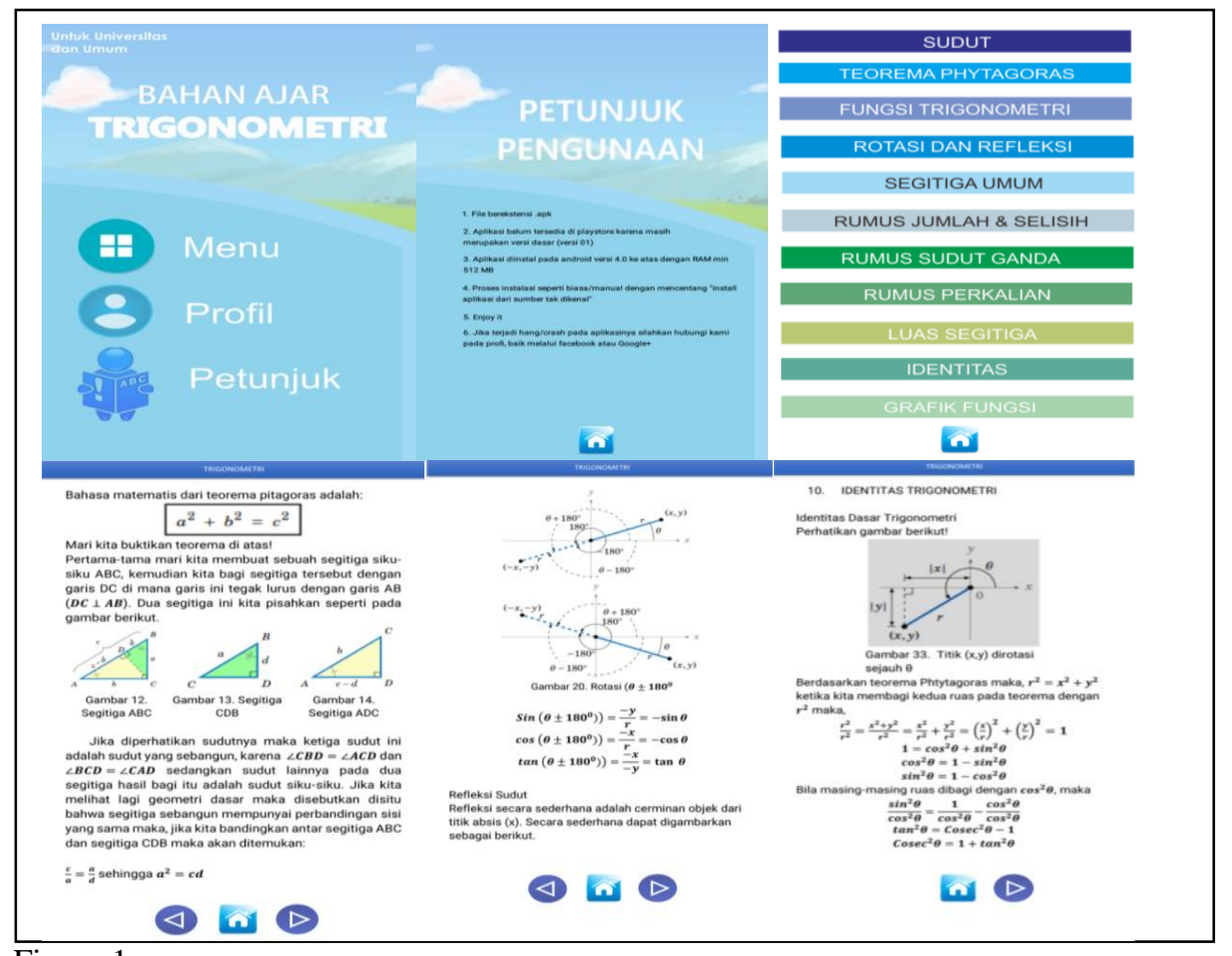

Figure 1

Screenshot of Trigonometry m-Learning base Android

This media is explicitly designed only for trigonometric teaching materials. But to make the implementation of trigonometric learning more effective, the learning process is carried out with the background of the Cooperative learning with Think Pair Share (TPS) models. There are three steps in TPS models: 1) Think. In these steps, a teacher asks students to think about a question or observation. In this step students used media. The students need to think about the answers to the problem in a few minutes. 2) Pair. The students discuss their solutions in a couple. They compare the responses to find the best, most convincing, or unique one. 3) Share. After seeing the answer, the teacher will call for the pair to share their result with the rest of the class (Rifa'i \& Lestari, 2018).

After we were integrating with media (M-Learning based on Android), all step will be: 1) The first stage is thinking, at this stage, the teacher asks a question or problem associated with the lesson using media, and ask students to use a few minutes to think for themselves. The second stage is a pairing, at which point the teacher asks the students to pair up and discuss what they have gained (Umam et al., 2017). The third stage is sharing, at this stage, the teacher asks the pairs of students to share their work using media with the whole class, and other students give feedback from their friend's performance. The combination of both is very suitable for trigonometric learning 
because trigonometry with its visualization requires proper concentration and interactive with the media. Those characteristics make TPS applicable to mathematics learning (Afthina\& Pramudya, 2017). Large groups certainly cannot achieve this condition. However, it will be performed if there is a small group of two or three people. Work results in small groups (pair) through media exploration will be used by all or large groups when students make presentations (share). With this approach, students are expected to be able to communicate the results of their thoughts so that they can further strengthen their understanding of the concepts that have been achieved.

\section{Cognitive style}

In addition to media and learning models, there are still many things that might affect student learning achievement, one of which is the student's cognitive style. Individual student differences need to be considered in increasing students' understanding of mathematical concepts. The differences of each will, of course, affect ability construction of one's knowledge so that they can understand and process information obtained. The difference between each in how to compile and process information is often known as cognitive style. Cognitive style is the way students compile and process information and experiences that come from the surrounding world (Saputra \& Dahlan, 2018). Students 'cognitive style of mathematics is one of the factors that determine students' success in learning mathematics.

Students generally show different responses when faced with a situation and the same learning conditions, some were very enthusiastic about specific learning methods, but there were those who were less enthusiastic (Makur, Prahmana, \& Gunur, 2019). According to Witkin (1977), the difference in response raised by someone is related to differences in approach perceptual and intellectual characteristics of the person who brought it to respond to the situation at hand, and this difference was later referred to as the difference in cognitive style. Some other experts argue that cognitive style is a bridge between cognition and actions that show one's personality (Stenberg and Grigorenko, 1997).

Basey (2009) revealed that cognitive style is a process of the method of control that arises in students who can situationally determine students' conscious activities in organizing, organizing, receiving, and disseminating information and also learning the behavior of these students. Thus, cognitive style can be said as a way students to capture data, process information and execute information in action or reaction when the learning process takes place that the student is doing consistently.

Cognitive style can be distinguished based on several ways of grouping, one of them conducted by Witkin (1977) who identified and grouped a person based on the characteristics of the global analytic continuum. Based on this grouping method, Witkin divided the cognitive style into two groups, namely the field dependent (FD) and field independent (FI) cognitive styles. A person with a field dependent cognitive style is a person who thinks globally, accept existing structures or information, have cultural orientation, choose professions that are social skills, tend to follow the goals and knowledge that already exists. They tend to prioritize external motivation, while people 
who have a cognitive field independent style are someone with characteristics able to analyze objects apart from their environment, able to organize objects, have an impersonal orientation, choose individual professions, and prioritize motivation from within themselves (Bamiro, 2015).

In the learning process, students who have field-dependent cognitive style characteristics will tend to focus on the general picture; only follow existing information; but can work together well, because of its social orientation. Whereas someone with particular independent field cognitive style will tend to be able to find more information outside the existing content; able to distinguish an object from an object around it more efficiently and tends to be more analytical, and his motivation depends on internal motivation.

\section{METHOD}

\section{Model and Design}

This research model is quantitative research. The design of this research was a quasiexperiment with control class without pre-test. This design was chosen because this research focused on investigating the effectiveness of collaboration TPS Learning Model and m-Learning based on Android to assist students in the understanding of trigonometry concepts. In this study, we wanted to compare the efficacy of a new approach to learning strategy with current learning strategy. We did not measure improvement in conceptual understanding after treatment.

Before the experiment, a test on cognitive style was administered to know the student's cognitive style. Both students in experiment and control class were divided based on their cognitive style into FI and FD groups. The experimental class was taught by using collaboration TPS Learning Model and m-Learning based on Android and the control class by using conventional (expository) teaching.

This research used the factorial design with treatment by level design. Fraenkel \& Wallen (2009) described that the factorial design extends the number of relationships that may be examined in an experimental study. The factorial design applied in this research was 2 × 2 factorial design.

Another advantage of a factorial design is that it allows a researcher to study the interaction of an independent variable with one or more other variables, sometimes called moderator variables. The moderator variable can be a treatment variable or subject characteristic variables (Fraenkel \& Wallen, 2009). In this research, we used cognitive style as the moderator variable.

\section{Participants}

There were 80 university students of the Mathematics Department at STKIP Santu Paulus, Ruteng, East Nusa Tenggara, Indonesia involved in this research who were chosen randomly. The students' age between 18-20 years old. This sample of 80 students was then grouped into experiment and control group, each of which contains 40 students. Students in both groups were classified into two groups based on their cognitive style so that we had 20 students with field Independent cognitive style and 20 
students with field-dependent cognitive style. This situation can be presented as in table1 below.

Table 1

The Distribution of Research Participant

\begin{tabular}{llll}
\hline \multicolumn{3}{c}{ Learning } \\
\hline & Integration Android Apps and TPS Models & Conventional \\
\hline cognitive style & FI & 20 & 20 \\
& FD & 20 & 20 \\
\hline
\end{tabular}

The number of students from all research classes taking the GEFT test was 102 students; there are six students from the initial sample (108 students) who are not taking the GEFT test. Test results show as many as 40 students who have cognitive style FI, 40 cognitive styles FD and 11 students do not have cognitive style tendencies FI or FD (Neutral). The distribution of this cognitive style is quite balanced especially for the FI and FD cognitive styles that are in focus in this research. From this result, the number of samples taken for research analysis is 80 students (FI and cognitive style groups FD).

\section{Data Collection}

The data in this research were obtained from a test to measure students' understanding of trigonometry concept sand Group Embedded Figures Test (GEFT) to identify students' cognitive styles either Field-Dependent (FD) or Field-Independent (FI). The test of students' understanding of trigonometry concepts assessed three aspects of understanding, that is, translation, interpretation, and extrapolation. The test was developed by the researchers and was given to both the experimental and control group at the end of the study.

\section{Data Analysis}

The collected data were then analyzed using two-way ANOVA at a 5\% level of significance. ANOVA was employed because we wanted to see the main effect and the interaction effect. Before implementing two-way ANOVA, the data were tested for normality and homogeneity. Kolmogorov-Smirnov test was employed to check for normality and homogeneity was tested using Levene's test.

\section{FINDINGS}

Two-way ANOVA was conducted to determine the difference in understanding of trigonometry concepts between the experimental and control groups based on cognitive style. Before the data were analyzed to test the hypothesis, a preliminary test was done to check for normality and homogeneity. The results of this initial test were shown in Table 2 and Table 3.

Table 2

Result of Normality Test Using Kolmogorov-Smirnov

\begin{tabular}{llll}
\hline Group & \multicolumn{3}{l}{ Kolmogorov-Smirnov } \\
\cline { 2 - 4 } & Statistic & df & Sig. \\
\hline Experiment & .162 & 40 & .200 \\
Control & .111 & 49 & .200 \\
\hline
\end{tabular}


The result of the Kolmogorov-Smirnov test indicated that the data about students' understanding of trigonometry concepts have a normal distribution for both groups. In Table 3, we show the result of Levene's test for homogeneity.

Table 3

The Result of Levene's test for Homogeneity

Dependent Variable: understanding of trigonometry concepts

\begin{tabular}{llll}
\hline $\mathrm{F}$ & $\mathrm{df} 1$ & $\mathrm{df} 2$ & Sig. \\
\hline 1.237 & 3 & 76 & .302 \\
\hline
\end{tabular}

Table 3 shows that there was no significant variance-covariance difference among dependent variables for all levels of independent variables (Sig. $=0,302 p>0.05$ ). It means that the data were homogeneous. As a result, two-way ANOVA was performed to determine if differences exist between the experimental and control groups regarding their conceptual understanding of trigonometry concept based on cognitive style.

The group means and standard deviations, and the results of the two-way ANOVA are shown in Tables 4 and 5, respectively.

Table 4

Mean and Standard Deviation of Students' Score on an Understanding of Trigonometry Concepts Viewed from the Cognitive Style

\begin{tabular}{lllll}
\hline Group & cognitive style & $\mathrm{N}$ & Mean & Std. Dev \\
\hline Experiment & FI & 20 & 86 & 7.317966 \\
& FD & 20 & 74.50 & 8.054093 \\
& Total & 40 & 82.25 & 8.938 \\
\hline Control & FI & 20 & 80.25 & 8.769715 \\
& FD & 20 & 69.12 & 4.898644 \\
& Total & 40 & 77.25 & 7.638 \\
\hline
\end{tabular}

From Table 4. it can be seen that the average score of students' understanding of trigonometry concepts in the experiment group is greater than those in the control group. This result indicates that Integration m-Learning based on Android and TPS Model has a better effect on students' understanding of trigonometry concepts than that of conventional teaching. Table 4 also showed that the average score of understanding of trigonometry concepts for students with FI cognitive style is better than students with FI cognitive style in both experiment and control groups.

Table5

Analysis with Two-Way ANOVA

Dependent Variable: understanding of trigonometry concepts

\begin{tabular}{llllll}
\hline \multicolumn{1}{c}{ Source } & Type III Sum of Squares & df & Mean Square & F & Sig. \\
\hline Learning & 512.578 & 1 & 512.578 & 9.348 & .003 \\
CS & 2338.203 & 1 & 2338.203 & 42.643 & .000 \\
Learning * CS & 9.453 & 1 & 9.453 & .172 & .679 \\
Error & 4167.188 & 76 & 54.831 & & \\
Total & 490243.750 & 80 & & & \\
\hline
\end{tabular}


Based on the table 5, we can conclude the following.

1. Understanding of trigonometry concepts of students who are taught with collaboration TPS Learning Model and m-Learning based on Android is higher than those who are trained with conventional teaching.

There is no interaction between collaboration TPS Learning Model and m-Learning based on Android and students' cognitive style on an understanding of trigonometry concepts. This result indicates that Integration TPS Learning Model and m-Learning based on Android significantly improves understanding of trigonometry concepts for students with FI and FD cognitive style.

\section{DISCUSSION}

The general purpose of this study is to obtain a complete picture of the effect of collaboration TPS Learning Model and m-Learning based on Android treatment on an understanding of trigonometry concept for university students. This treatment for seven times the meeting is applied in STKIP Santu Paulus. The results of two-way analysis of variance (ANOVA) found that there are differences in understanding of trigonometry concept of students group using collaborative learning and student group in conventional learning. This test the understanding of trigonometry concept of the group of students using the collaboration TPS Learning Model and m-Learning based on Android is higher than the understanding of trigonometry concept students using traditional learning.

Several reasons, collaboration TPS Learning Model and m-Learning based on Android facilitated the place that students can develop their skill. According to research by Kularbphettong et al. (2015) state that mobile learning had significantly better performance in learning achievements. This system can be beneficial to use in different courses so that students can enhance and improve their ability and also this system supports teachers to the handle and manage their class. In the other, this collaboration learning as a formula to the made a good scenario, while for the student with different cognitive style to do exploration.

Drigas \& Pappas (2015) in their study about the most representative studies of recent years concluded that involving online and mobile applications and tools for mathematics have a positive effect on the educational process. They presented some innovate applications which are addressed by kindergarten children to university students. These apps could be used to improve their arithmetic skills, numerosity, for graphs' representation, geometrical objects construction, algebra problem solving and mathematical programming. Besides, Drigas \& Pappas (2015) described that online and mobile learning applications motivated students, making mathematics course more enjoyable and interactive than standard teaching practices.

During the experiment using collaboration learning, the researcher also observes and gets visible results during practice in the field. The results show that there are mostly students who are actively involved and cooperatively use their cellphones to carry out tasks during the learning activities. Through an excellent and straightforward application design, it will allow students to use their cells into learning to build their knowledge and 
understanding of trigonometric materials according to the guidance and support of the instructor.

The application of the TPS learning model assisted by m-Learning base on Android as interactive media has an impact on the classroom situation and students perform. Changes in the condition of students include active students, the courage to make presentations, and the learning atmosphere to be fun. In the second cycle, the learning process becomes better because the application of collaborative learning can increase student activity through group discussion as argued by Zubainur \& Abidin (2018) saying discussion techniques are teaching and learning techniques carried out by teachers in schools. In this discussion, the teaching and learning process takes place, where the interaction between two or more individuals involved exchanging experiences, information, solving problems can occur, and all are active. The use of interactive media can enhance teaching processes and outcomes concerning the level of thinking of students. The level of human thought follows the stage of development starting from real thinking towards abstract thinking, starting from uncomplicated reasoning to intricate thinking patterns.

The use of media is closely related to the stages of thinking because through learning media abstract things can be concretized and complicated things can be simplified (Afthina \& Pramudya, 2017; Wahyuni, 2018). The advantages of applying the TPS learning model assisted by interactive media in history learning include: 1) motivating and attracting students' curiosity for learning History. 2) stimulating students' creativity in the form of ideas, ideas, and breakthroughs in solving problems, and 3) increasing student learning activities.

The following hypothesis test results found that there was no interaction between collaborative learning and cognitive styles towards an understanding of trigonometric concepts. This result indicates that collaboration TPS Learning Model and m-Learning based on Android significantly improves understanding of trigonometry concepts for students with FI and FD cognitive style. Also, students with FI cognitive style provide better results than FD cognitive style in both of the experimental and control classes. Between the cooperative learning model type TPS which is accompanied by the use of m-Learning base on Android Applications and traditional learning have a different result for those learners with different cognitive style. It was found that students with a different cognitive style had different performance in different treatment.

In this present study, we found that collaboration TPS Learning Model and m-Learning based on Android given the excellent result both for the FI and FD class than conventional class. This collaborative learning is one form of learning model that emphasizes the participation and activities of students in searching for their material (information). They can explore all information by them self and by using Android apps. So that with Integration m-Learning based on Android and TPS Learning Model, understanding of trigonometry concepts for students with FI and FD cognitive style can develop because students are given the freedom to find solutions from problems. They can learn without having to depend on explanations from the lecture, but they can explore all of the issues with friends. 
Students who are FI cognitive styled have a high level of independence in looking at a stimulus without dependence on the lecture. This result corresponds with the theory proposed by Witkin (1977), students with a field-independent cognitive style tend to deal with things in work independently. The behaviors of students with fieldindependent cognitive style rational or indifferent (Lu \& Lin, 2018). These students respond to a task tend to lean or rely on the conditions of the self.

Based on the results of observations in the class, the activities of students who have a cognitive style FI are taught by collaboration learning seemed more enthusiastic than students who followed traditional learning. Exploration activities carried out independently by students using Android apps. The data available indicate that fieldindependent students in traditional class obtain worse results than their fieldindependent in experiment class.

Students who have an FD cognitive style are usually more challenging to make solving a problem independently. The students who have an FD cognitive style are very dependent on others. Students who have an FD cognitive style tend to have a degree of independence in looking at a stimulus without dependence on external factors. Students who have a cognitive style of FD depend on outside sources of information (Taram. 2017). In this collaboration learning models, students are cognitively styled FD is given space to construct knowledge with their respective teams actively. This space allows students who have a cognitive style FD can collaborate with a group of friends in solving problems without depending on the explanation from the teacher.

This collaborative learning is one of the facilitators that accommodates FD students in learning. Pair activities and sharing made FD's students are provided. At this stage, students who are FD can slowly understand a trigonometry concept on the results of a peer review which is then refined by the lecturer. In the experimental class, researchers see that students with a field dependent cognitive style prefer to work on the worksheet by working together rather than working alone. They often ask friends more than asking the teacher. This result is consistent with previous studies by Lu \& Lin (2018). Their research about effect collaborative learning and cognitive style showed that in collaborative learning, FD cognitive style not only had more discussion messages, but they were also more active to discuss with one another in the group. The learners with FD cognitive style are better and more susceptible to the external environment compared with FD learners in the conventional class. However, in the control class, at the beginning of the study paying attention to the teacher's explanation seriously but at the end of the lesson, it was less severe to pay attention to the teacher's comment in interpreting trigonometric concepts. The students' with FD cognitive style in the control class, look less active in doing individual evaluation exercises. However, when done in the form of groups they look active in presenting/responding/asking questions to friends. Aforementioned indicates that they always need encouragement from outside themselves in doing something.

\section{CONCLUSION AND SUGGESTION}

From the result of the study that had been done, it can be concluded that the students' understanding on trigonometry concepts will become better if they are taught with the 
collaboration of TPS Learning Model and m-Learning based on Android than with conventional teaching (expository). Besides, it can also be concluded that there is no significant interaction effect between collaboration TPS Learning Model and mLearning based on Android and cognitive style (FI and FD) of the students on the students' understanding of trigonometry concepts.

Since collaboration TPS Learning Model and m-Learning based on Android is effective in improving the students' understanding of trigonometry concepts, it is then suggested to mathematics teachers or lecture to consider the use of this collaboration learning in teaching mathematics, especially in teaching trigonometry.

\section{REFERENCES}

Afthina, H., \& Pramudya, I. (2017). Think pair share using realistic mathematics education approach in geometry learning. J. of Physics: Conf. Series, 895(1), 012025.

Astra, I. M., Nasbey, H., \& Nugraha, A. (2015). Development of an android application in the form of a simulation lab as learning media for senior high school students. Eurasia J. of Mathematics, Science \& Technology Edu., 11(5), 1081-1088.

Bamiro, A. O. (2015). Effects of guided discovery and think-pair-share strategies on secondary school students' achievement in chemistry. SAGE Open, 5(1), 1-7. https://doi.org/10.1177/2158244014564754.

Bassey, S. W., Umoren, G., \& Udida, L. A. (2007, February). Cognitive styles, secondary school students' attitude and academic performance in chemistry in Akwa Ibom State-Nigeria. Paper presented at the 2-International Conference to Review Research in Science, Technology and Mathematics Education, India.

Drigas, A. S., \& Pappas, M. A. (2015). A review of mobile learning applications for mathematics. iJIM, 3(3), 18-23. http://dx.doi.org/10.3991/ijim.v9i3.4420.

Dündar, S. (2015). Mathematics teacher-candidates' performance in solving problems with different representation styles: The trigonometry example. EURASIA Journal of Mathematics, Science and Technology Education, 11(6), 1379-1397.

Elmunsyah, H. (2014). A national education policy-based ICT model for Indonesian vocational high schools (VHS). Global J. of Engineering Education, 16(3), 136-140.

Etcuban, J. O., \& Pantinople, L. D. (2018). The effects of mobile application in teaching high school mathematics. International Electronic Journal of Mathematics Education, 13(3), 249-259 https://doi.org/10.12973/iejme/3906.

Fraenkel, J. R., \& Wallen, N. E. (2009). How to design and evaluate research in education. New York. McGraw-Hill Companies.

Galligan, L., Loch, B., McDonald, C., \& Taylor, J. A. (2010). The use of tablet and related technologies in mathematics teaching. Australian Senior Math. J., 24(1), 38-51.

Gunawan, A. A., Hartanto, B., Mili, A., Budiharto, W., Salman, A. G., \& Chandra, N. (2017). Development of affordable and powerful swarm mobile robot based on smartphone, android and IOIO board. Procedia Computer Science, 116, 342-350. 
Harrington, M. A., Lloyd, A., Smolinski, T., \& Shahin, M. (2016). Closing the gap: First year success in college mathematics at an HBCU. Journal of the Scholarship of Teaching and Learning, 16(5), 92-106.

Jelatu, S., Sariyasa, \& Ardana, I. M. (2018). Effect of GeoGebra-aided REACT strategy on understanding of geometry concepts. International Journal of Instruction, 11(4), 325-336. https://doi.org/10.12973/iji.2018.11421a.

Kularbphettong, K., Putglan, R., Tachpetpaiboon, N., Tongsiri, C., \& Roonrakwit, P. (2015). Developing of mLearning for discrete mathematics based on android platform. Procedia-Social and Behavioral Sciences, 197, 793-796.

Laouris, Y., \& Laouri, R. (2008). Can Information and Mobile Technologies serve to close the gap and accelerate development? The Journal of New Paradigm Research 64(4), 254-275. https://doi.org/10.1080/02604020802189534.

Leasa, M., \& Corebima, A. D. (2017). The effect of numbered heads together (NHT) cooperative learning model on the cognitive achievement of students with different academic ability. Journal of Physics: Conference Series, 795(1), 012071.

Lee, K. B. (2011). Developing mobile collaborative learning applications for mobile users. International Journal of Interactive Mobile Technologies (iJIM), 5(4), 42-48.

Lu, H., \& Lin, P. (2018). A study on the effect of cognitive style in the field of STEM on collaborative learning outcome. International Journal of Information and Education Technology, 8(3), 194-198. https://doi.org/10.18178/ijiet.2018.8.3.1032.

Makur, A. P., Prahmana, R. C. I., \& Gunur, B. (2019). How mathematics attitude of mothers in rural area affects their children's achievement. Journal of Physics: Conference Series, $1188(1), 012009$.

Martono, K. T., \& Nurhayati, O. D. (2014). Implementation of android based mobile Learning application as a flexible learning media. Int. J. of Comp. Sci., 11(3), 168-174.

Meiliana, Septian, I., Alianto, R. S., \& Daniel. (2018). Comparison analysis of android GUI testing frameworks by using an experimental study. Procedia Computer Science, 135, 736-748. https://doi.org/10.1016/j.procs.2018.08.211.

Mouza, C., \& Barrett-Greenly, T. (2015). Bridging the app gap: An examination of a professional development initiative on mobile learning in urban schools. Computers and Education. 88. 1-15.

NCTM (2000). Principles and standards for school mathematics. Reston, VA: National Council of Teachers of Mathematics.

Popescu, E., Stefan, C., Ilie, S., \& Ivanović, M. (2016). EduNotes-A mobile learning application for collaborative note-taking in lecture settings. In International Conference on Web-Based Learning (pp.131-140). Cham: Springer.

Rifa'i, A., \& Lestari, H. P. (2018). The effect of think pair share (TPS) using the scientific approach on students' self-confidence and mathematical problem-solving. Journal of Physics: Conference Series, 983(1), 012084. 
Saputra, E., \& Dahlan, J. A. (2018). The enhancement of spatial levels reviewed from students' cognitive styles. Journal of Physics: Conference Series, 1028(1), 012093.

Sariyasa. (2017). Learning environment to enhance students' engagement in learning geometry. Journal of Physics: Conf. Series, 824(1), 1-5.

Taram, A. (2017). Probabilistic thinking ability of students viewed from their field independent and field dependent cognitive style. Journal of Physics: Conference Series, 824(1), 012050.

Tatar, E., Okur, M., \& Tuna, A. (2008). A study to determine learning difficulties in secondary mathematics education. Kastamonu Education Journal, 16(2), 507-516.

Toktarova, V. I., Blagova, A. D., Filatova, A. V., \& Kuzmin, N. V. (2015). Design and implementation of mobile learning tools and resources in the modern educational environment of the university. Review of European studies, 7(8), 318-324. https://doi.org/10.5539/res.v7n8p318.

Tuna, A. (2011). The effect of the 5e learning cycle model on students' mathematical thinking and academic achievements in teaching trigonometry (Unpublished doctoral dissertation). Gazi University, Ankara.

Umam, K., Suswandari, N. A., Wibowo, I. T., \& Rohim, S. (2017). The effect of thinkpair-share cooperative learning model assisted with ICT on mathematical problemsolving ability among junior high school students. In Proceedings of the 26th International Conference on Computers in Education (ICCE 2018) (pp.94-98). Christchurch, New Zealand.

Usman, M. H., \& Hussaini, M. M. (2017). Analysis of students' error in learning of trigonometry among senior secondary school students in Zaria Metropolis, Nigeria. IOSR Journal of Mathematics, 13(2), 01-04. https://doi.org/10.9790/5728-1302040104.

Wahyuni, A. (2018). Comparison effectiveness of cooperative learning types STAD with cooperative learning type TPS in terms of mathematical method of Junior High School students. Journal of Physics: Conference Series, 1013(1), 012212.

Weber, K. (2005). Students' understanding of trigonometric functions. Mathematics Education Research Journal, 17(3), 91-112.

Witkin, H. A., Moore, C. A., Goodenough, D. R., \& Cox, P. W. (1977). Fielddependent and field-independent cognitive styles and their educational implications. Review of educational research, 47(1), 1-64.

Zakaria, E. (2010). Analysis of studentsee error in learning quadratic equations. International Education Studies, 3(3), 105-110.

Zubainur, C. M., \& Abidin, T. F. (2018). The quality of mathematics learning material using a modification of think pair share (TPS) model. Journal of Physics: Conference Series, 1088(1), 012097. 